\title{
Profil Pasien Pasca Laparotomi di ICU RSUP Prof. Dr. R. D. Kandou Manado Periode Januari 2015 sampai Desember 2017
}

\author{
${ }^{1}$ Pratiwi N. Tanio \\ ${ }^{2}$ Diana C. Lalenoh \\ ${ }^{2}$ Mordekhai L. Laihad
}

\author{
${ }^{1}$ Program Studi Pendidikan Dokter Fakultas Kedokteran Universitas Sam Ratulangi Manado \\ ${ }^{2}$ Bagian Anestesiologi dan Terapi Intensif Fakultas Kedokteran Universitas Sam Ratulangi/ \\ RSUP. Prof. Dr. R. D. Kandou Manado \\ Email: pratiwinurtanio@yahoo.com
}

\begin{abstract}
Laparotomy is a surgical procedure involving an incision through the abdomen. Laparotomy can be performed on patients with hemoperitoneum due to abdominal trauma, gastrointestinal bleeding, acute abdominal pain, chronic abdominal pain, and if there is an intra-abdominal clinical finding that requires emergency surgery, such as pertonitis as well as ileus (obstruction or perforation). This study was aimed to obtain the profile of post laparotomy patients at ICU Prof. Dr. R. D. Kandou Hospital Manado from January 2015 to December 2017. This was a descriptive retrospective study using medical record data of post laparotomy patients at Prof. Dr. R. D. Kandou Hospital Manado. There were 107 post laparotomy patients at the ICU. The highest percentages were found in: peritonitis $(38.3 \%)$, males $(62 \%)$, and ages $45-64$ years $(50 \%)$. There were $87 \%$ of post laparotomy patients that used mechanical ventilators. The average of length of stay of post laparotomy patients in ICU was 7-14 days (33\%). There were 40 patients (37\%) in $24-48$ hours after admission in the ICU and caused by sepsis (77.5\%). Conclusion: Most post laparotomy patients were 45-64 years old, male, had main diagnosis as peritonitis, length of stay of 7-14 days, and used mechanical ventilators. Moreover, there were 40 patients died in 24-48 hours after admission.
\end{abstract}

Keywords: laparotomy, peritonitis, mortality, length of stay

\begin{abstract}
Abstrak: Laparotomi adalah suatu tindakan bedah berupa insisi pada dinding perut atau abdomen. Laparotomi dapat dilakukan pada pasien yang menderita trauma abdomen dengan hemoperitoneum, perdarahan gastrointestinal, nyeri abdomen akut, nyeri abdomen kronik, dan jika ditemukan kondisi klinis intra abdomen yang membutuhkan pembedahan darurat seperti peritonitis, ileus obstruksi, dan perforasi. Penelitian ini bertujuan untuk mengetahui profil pasien pasca laparotomi di ICU RSUP Prof. Dr. R. D. Kandou Manado periode Januari 2015 Desember 2017. Jenis penelitian ialah deskriptif retrospektif, menggunakan data rekam medik pasien pasca laparotomi di RSUP Prof. Dr. R. D. Kandou Manado. Hasil penelitian mendapatkan 107 orang pasien pasca laparotomi di ICU dengan diagnosis penyakit terbanyak pada peritonitis $(38,3 \%)$, jenis kelamin laki-laki $(62 \%)$, dan usia 45-64 tahun (50\%). Pasien pasca laparotomi banyak yang menggunakan ventilator mekanik (87\%). Rerata lama perawatan pasien pasca laparotomi di ICU 7-14 hari (33\%). Terdapat 40 orang yang meninggal (37\%) pada 24-48 jam dirawat di ICU, dan disebabkan oleh sepsis $(77,5 \%)$. Simpulan: Pasien pasca laparotomi terbanyak pada usia 45-64 tahun, jenis kelamin laki-laki, dengan diagnosis penyakit dilakukan laparotomi peritonitis, lama rawat ICU 7-14 hari, dan menggunakan ventilator mekanik. Didapatkan 40 pasien yang meninggal pada $24-48$ jam dirawat di ICU.
\end{abstract}

Kata kunci: laparotomi, peritonitis, mortalitas, lama rawat inap 
Laparotomi adalah suatu tindakan bedah berupa insisi pada dinding perut atau abdomen. ${ }^{1}$ Karakteristik pasien yang menjalani operasi laparotomi rata-rata berusia 15-75 tahun dengan perbandingan pria dan wanita sebesar 2:1. Etiologi paling sering ialah trauma dan kondisi lain yang menyertai seperti kerusakan viseral dan vaskular. ${ }^{2}$ Pada penelitian yang dilakukan di Rumah Sakit Universitas Jerman pada Januari sampai Juli 2015 tercatat 41 pasien pasca laparotomi yang dirawat di Intensive Care Unit (ICU) dengan rerata usia 21-83 tahun. ${ }^{3}$

Laparotomi dapat dilakukan pada pasien yang menderita trauma abdomen dengan hemoperitoneum, perdarahan gastrointestinal, nyeri abdomen akut, nyeri abdomen kronik, dan jika ditemukan kondisi klinis intra abdomen yang membutuhkan pembedahan darurat seperti peritonitis, ileus obstruksi dan perforasi. ${ }^{1}$ Beberapa indikasi utama dilakukannya tindakan operasi laparotomi yaitu perdarahan intra abdomen $(39,0 \%)$ dengan angka mortalitas $75,6 \%$, iskemia usus $(24,4 \%)$ dengan angka mortalitas $80,5 \%$, trauma abdomen $(23,5 \%)$ dengan angka mortalitas $75,5 \%$, serta obstruksi usus $15,7 \%$ dan penyakit divertikular $14,3 \% .{ }^{4}$ Rumah Sakit Nasional Chen Kung Universitas Taiwan mencatat sebanyak 340 operasi laparotomi selama periode Oktober 1993-Agustus 1996 dengan angka mortalitas mencapai $6,8 \%{ }^{5}$

Lama rawat inap pasien yang menjalani laparotomi tergantung pada penyulit pasca operasi. Lama perawatan pasien pasca operasi bervariasi yaitu sekitar 7-30 hari dengan rerata lama perawatan 7-14 hari. Hal ini dipengaruhi oleh mobilisasi dini setelah proses penyembuhan luka pasca operasi. ${ }^{4,6}$ Penelitian yang dilakukan di Rumah Sakit Dr. Sardjito Yogyakarta melaporkan sebanyak 82 operasi laparotomi karena trauma abdomen dengan tingkat mortalitas $18,3 \%$ dan rerata lama rawat 15 hari. $^{7}$

Penelitian di beberapa Universitas di Amerika Serikat menyebutkan bahwa pasien yang dirawat di ICU berisiko terkena infeksi nosokomial 5-8 kali lebih tinggi daripada pasien yang dirawat di ruangan lain. Infeksi nosokomial banyak terjadi pada kasus pasca operasi laparotomi, pemasangan infus, kateter, dan instrumen lain yang merupakan pintu masuk kuman. ${ }^{8}$ Survei oleh WHO, menunjukkan 5-34\% dari total infeksi nosokomial ialah infeksi luka operasi (ILO). ${ }^{9}$ Menurut penelitian Murtaza et al. ${ }^{10}$ di Pakistan, prevalensi ILO pasca laparotomi darurat lebih tinggi dibanding pasca laparotomi elektif.

Berdasarkan data awal yang diambil di ICU RSUP Prof. Dr. R. D. Kandou Manado terdapat 62 pasien pasca laparotomi yang dirawat di ICU pada bulan Januari sampai November 2017 dengan rerata lama rawat 2-5 hari. Penelitian ini bertujuan untuk mendapatkan profil pasien pasca laparotomi di ICU RSUP Prof. Dr. R. D. Kandou Manado periode Januari 2015 sampai Desember 2017.

\section{METODE PENELITIAN}

Jenis penelitian ini ialah deskriptif retrospektif dengan metode pengambilan sampel non probability sampling yaitu purposive sampling. Tempat penelitian di Intalasi Rekam Medik RSUP Prof. R. D. Kandou. Subjek penelitian ialah semua pasien pasca laparotomi yang dirawat di ICU RSUP Prof. R. D. Kandou periode Januari 2015 sampai Desember 2017.

\section{HASIL PENELITIAN DAN BAHASAN}

Jumlah pasien pasca laparotomi di ICU RSUP. Prof. Dr. R. D. Kandou Manado periode Januari 2015 sampai Desember 2017 sebanyak 107 kasus. Tabel 1 memperlihatkan bahwa pasien pasca laparotomi terbanyak pada jenis kelamin laki-laki 66 orang (62\%) dengan usia 45-64 tahun berjumlah 53 orang (50\%).

Tabel 2 menunjukkan bahwa diagnosis penyakit terbanyak yang dilakukan laparotomi ialah peritonitis berjumlah 41 kasus (38,3\%). Menurut data Rumah Sakit Sina di Tehran Iran, kasus laparotomi dengan diagnosis terbanyak yaitu apendisitis akut $(56,8 \%)$, diikuti oleh peritonitis $(14,4 \%)$, obstruksi $(7,9 \%)$, dan torsi kista ovarium $(24,5 \%) .{ }^{11}$ Laiang et al. ${ }^{12}$ menyatakan kasus laparotomi banyak dilakukan pada apendi- 
sitis dan trauma $(41 \%)$ dan lebih banyak pada laki-laki (70\%) dengan rerata usia 38 tahun.

Tabel 1. Distribusi jumlah dan persentase pasien pasca laparotomi berdasarkan jenis kelamin dan usia

\begin{tabular}{lccc}
\hline & Variabel & N & \% \\
\hline Jenis & Laki-laki & 66 & 62 \\
kelamin & Perempuan & 41 & 38 \\
& Jumlah & 107 & 100 \\
Usia & $0-14$ tahun & 2 & 2 \\
& 15-24 tahun & 13 & 12 \\
& 25-34 tahun & 13 & 12 \\
& 35-44 tahun & 8 & 7 \\
& 45-64 tahun & 53 & 50 \\
& $>65$ tahun & 18 & 17 \\
& Jumlah & 107 & 100 \\
\hline
\end{tabular}

Tabel 2. Distribusi jumlah dan persentase pasien pasca laparotomi menurut diagnosis penyakit.

\begin{tabular}{lcc}
\hline \multicolumn{1}{c}{ Variabel } & N & \% \\
\hline Diagnosis penyakit & & \\
Obstruksi usus & 22 & 20,6 \\
Peritonitis & 41 & 38,3 \\
Karsinoma & 23 & 21,5 \\
Batu CBD & 2 & 1,8 \\
Endometriosis & 2 & 1,8 \\
Kehamilan ektopik & 2 & 1,8 \\
terganggu & 1 & 1 \\
Hernia insisional & 3 & 2,8 \\
Kista ovarium & 1 & 1 \\
Perdarahan post & 1 \\
partum & 1 & 1 \\
Splenomegali & 9 & 8,4 \\
Trauma & 107 & 100 \\
Jumlah & &
\end{tabular}

Dari 107 pasien yang dilakukan tindakan laparotomi, 40 orang di antaranya meninggal dunia pada rata-rata 24-48 jam setelah dirawat di ICU. Kematian ini diakibatkan karena adanya penyakit penyerta lainnya seperti sepsis, obstruksi usus, syok hipovolemik dan sindrom uremikum. Pada penelitian ini penyebab terbanyak ialah sepsis sebanyak 31 kasus $(77,5 \%)$ (Tabel 3). Green ${ }^{13}$ mendapatkan bahwa $70 \%$ pasien pasca laparotomi mengalami komplikasi diantaranya infeksi luka, hematoma, sepsis, dan infark miokard dengan penyebab utama kematian yaitu sepsis sebesar 42\%, kanker 29\%, dan obstruksi usus $4 \%$. Ilham ${ }^{14}$ melaporkan bahwa pasien laparotomi yang keluar dari ICU dengan sebab kematian sebesar $60 \%$ dan kesembuhan $40 \%$. Hal ini dapat diartikan bahwa 6 dari 10 pasien pasca laparotomi prognosisnya berakhir buruk yaitu kematian.

Tabel 3. Distribusi jumlah dan persentase waktu kematian dan penyebab kematian pasien pasca laparotomi

\begin{tabular}{ccc}
\hline Variabel & $\mathbf{N}$ & $\mathbf{\%}$ \\
\hline Waktu kematian & & \\
$<24$ jam & 4 & 10 \\
$24-48$ jam & 15 & 37,5 \\
48-72 jam & 7 & 17,5 \\
$>$ 72 jam & 14 & 35 \\
Jumlah & 40 & 100 \\
\hline Penyebab kematian & & \\
Sepsis & 31 & 77,5 \\
Obstruksi usus & 3 & 7,5 \\
Syok hipovolemik & 5 & 12,5 \\
Sindrom Uremikum & 1 & 2,5 \\
Jumlah & 40 & 100 \\
\hline
\end{tabular}

Pasien pasca laparotomi banyak yang menggunakan ventilator mekanik yaitu berjumlah 93 orang (87\%). Namun, pada penelitian ini penulis tidak mendapatkan data waktu pemakaian ventilator pada pasien pasca laparotomi dikarenakan data rekam medik yang kurang lengkap. Lama rawat di ICU pasien pasca laparotomi terbanyak pada 7-14 hari (33\%). Lama rawat pasien yang menjalani laparotomi tergantung pada penyulit pasca operasi. Lama perawatan pasien pasca operasi bervariasi yaitu sekitar 7-30 hari dengan rerata lama perawatan 7-14 hari. Hal ini dipengaruhi oleh mobilisasi dini setelah proses penyembuhan luka pasca operasi. ${ }^{4,6}$ 
Tabel 4. Distribusi jumlah dan persentase penggunaan ventilator dan lama rawat di ICU pasca laparotomi

\begin{tabular}{cccc}
\hline & Variabel & $\mathbf{N}$ & $\mathbf{\%}$ \\
\hline $\begin{array}{c}\text { Penggunaan } \\
\text { ventilator } \\
\text { mekanik }\end{array}$ & Ya & 93 & 87 \\
& Tidak & 14 & 13 \\
& Jumlah & 107 & 100 \\
\hline Lama rawat ICU & 1 hari & 14 & 13 \\
& 2 hari & 14 & 13 \\
& 3 hari & 9 & 8 \\
& 4 hari & 5 & 5 \\
& 5 hari & 7 & 7 \\
& 6 hari & 12 & 11 \\
& $7-14$ hari & 35 & 33 \\
& $>$ 14 hari & 11 & 10 \\
& Jumlah & 107 & 100 \\
\hline
\end{tabular}

\section{SIMPULAN}

Dari hasil penelitian ini dapat disimpulkan bahwa pasien pasca laparotomi yang dirawat di ICU RSUP Prof. Dr. R. D. Kandou Manado periode Januari 2015 sampai Desember 2017 yang terbanyak ialah jenis kelamin laki-laki, usia 4564 tahun, diagnosis penyakit peritonitis, waktu kematian pasien pasca laparotomi rata-rata 24-48 jam, dan penyebab utama kematian ialah sepsis, Sebagian besar menggunakan ventilator mekanik dengan lama perawatan pasien pasca laparotomi rata-rata 7-14 hari.

\section{SARAN}

Disarankan melakukan penelitian lanjut untuk mencari hubungan antar variabel dengan pasien pasca laparotomi serta komplikasi yang terjadi pasca operatif.

Diperlukan perbaikan data dan peningkatan pengelolaan data pasien di Instalasi Rekam Medik RSUP Prof. Dr. R. D. Kandou Manado untuk menunjang penelitian yang lebih akurat.

\section{DAFTAR PUSTAKA}

1. Sjamsuhidajat J. Buku Ajar Ilmu Bedah (2nd ed). Jakarta: EGC, 2005; p. 620-38.

2. Jaffe RA, Schmiesing C, Golianu B. Anesthesiologist's Manual of Surgical
Procedures (5th ed.). Philadelphia: Lippincott Williams \&Wilkins, 2013.

3. Schreiber J, Nierhaus A, Vettorazzi E, Braune SA, Frings DP, Vashist Y, et al. Rescue bedside laparotomy in the intensive care unit in patients too unstable for transport to the operating room. Crit Care. 2014;18(3):R123.

4. Stephens N, Dolan R, Dorrance H. (2015). The emergency laparotomy; postoperative mortality and length of stay in hospital. Int J Surg. 2015;23(S1):S111.

5. Simanjuntak S. Prevalensi infeksi pada tempat operasi herniorafi dengan mesh di RSCM tahun 2006-2007.

6. Abelha FJ, Castro MA, Landeiro NM, Neves AM, Santos CC. Mortalidade e o tempo de internação em uma unidade de terapia intensiva cirúrgica. Revista Brasileira de Anestesiologia. 2006; 56(1):34-45.

7. Mozart, Pusponegoro AD. Evaluasi kejadian infeksi luka operasi pada operasi akut abdomen bersih dan bersih tercemar di IGD RSCM 1996. Jakarta: Dept. Ilmu Bedah FKUI/RSCM, 1996.

8. Zulkarnain I. Infeksi nosokomial. In: Buku Ajar Ilmu Penyakit Dalam III (5th ed). Jakarta: Fakultas Kedokteran Universitas Indonesia, 2009; p. 2906-10.

9. Singhal H, Kaur K, Zammit C. Wound infection. [cited 2008 Apr 5]. Available from: http://www.emedicine.com.

10. Murtaza B, Saeed S, Sharif MA. Postoperative complication in emergency versus elective laparotomies at a peripheral hospital. J Ayub Med Coll Abbottabad. 2010;22:42-7.

11. Mardanloo A, Laal M. Acute abdomen; pre and post-laparotomy diagnosis. IJCRIMPH . 2009;1(5):157-65.

12. Scriba MF, Laing GL, Bruce JL, Clarke DL. Repeat laparotomy in a developing world tertiary level surgical service. Am J Surg. 2015;210(4):755-8.

13. Green G. (2013). Emergency laparotomy in octogenarians: A 5-year study of morbidity and mortality. World J Gastrointest Surg. 2013;5(7):216.

14. Ilham MP. Rerata waktu penggunaan ventilator pada pasien surgical ICU RSUP Dr. Kariadi Semarang pada bulan Januari 2010 sampai Januari 2011 [Skripsi]. Semarang: Fakultas Kedokteran Undip; 2011. 